\title{
Effects of Neotyphodium endophyte infection on seed viability and germination vigor in Lolium multiflorum under accelerated ageing conditions
}

\author{
P.E. GUNDEL, J.B. LANDESMANN, M.A. MARTÍNEZ-GHERSA and C.M. GHERSA \\ IFEVA, Departamento de Recursos Naturales y Ambiente, Facultad de Agronomía, Universidad de Buenos Aires. Av. San Martín \\ 4453, C1417DSE, Buenos Aires, Argentina \\ gundel@ifeva.edu.ar
}

\begin{abstract}
Neotyphodium endophytes are obligate vertically-transmitted endo-symbionts of Lolium multiflorum grass. Thus, the success of endophyte is tied with the success of the seed. Here we present results from experiments aiming to test the effect of endophyte infection on seed viability and germination vigour. Endophyteinfected and non-infected seeds of three L. multiflorum accessions were compared under accelerated ageing conditions $\left(40^{\circ} \mathrm{C}\right.$ and $\approx 15 \%$ moisture content). Endophyte negatively affected seed viability and seed germination vigour in only one of the evaluated accessions. The effect of endophyte presence on seed quality in pasture grasses could depend on the population genetic background, and be related to direct or indirect effects of fungal infection on seed morphological or physiological characteristics. Keywords: Lolium multiflorum, Neotyphodium endophyte, seed quality, accelerated ageing
\end{abstract}

\section{Introduction}

Lolium multiflorum is an annual cool season grass species widely spread in Argentinean Pampas (Soriano et al. 1992). It is used as winter forage in many livestock production systems (De Battista 2005). This species establishes a symbiosis with Neotyphodium occultans endophyte fungus (Moon et al. 2000). Endophyteinfected plants produced more seeds and roots (Vila-Aiub et al. 2005) and were less attacked by aphids than non-infected ones (Omacini et al. 2001). Moreover, infected and non-infected seeds displayed dissimilar germination pattern (Vila-Aiub et al. 2005), based on different water (Gundel et al. 2006a), thermal and light quality (Gundel et al. 2006b) requirements.

Changes in endophyte frequency in a seed lot can be explained by two causes: differential death rates between endophytes and host seeds, and differential death rate of non-infected and infected seeds. Under storage conditions, seeds remain viable for longer periods than endophyte (Rolston et al. 1986; Welty et al. 1987; Medvescigh et al. 2004). However, under buried conditions, endophyte-infected seeds did not have a higher survival rate than non-infected ones (Hume \& Barker 2005).

Table 1 Endophyte infection level (\%) of biotypes of L. multiflorum accessions, Traditional, Lucero and Picaflor (on 100 evaluated seeds each).

\begin{tabular}{lcc}
\hline Accession & Biotype & Endophyte Infection level (\%) \\
\hline Traditional & E+ & 89 \\
& E- & 27 \\
Lucero & E+ & 90 \\
& E- & 2 \\
Picaflor & E+ & 86 \\
& E- & 4 \\
\hline
\end{tabular}

Accelerated ageing experiments have been used as fast tests to assess seed quality. Under this test, seeds are exposed to a deteriorative condition by means of high temperature and seed moisture content, and the dynamics of seed viability in relation to time is evaluated. Although results from this kind of test do not necessarily correlate with seed performance in the field, they are a good predictor of seed quality (McDonald 1998), and in particular for L. multiflorum, could indicate field performance (Marshall \& Naylor 1985). In this paper we use the results from accelerated ageing tests to estimate the effects of endophyte infection on host L. multiflorum seed longevity and germination vigour.

\section{Materials and Methods}

\section{Seed origin and management of the after-ripening}

Seeds of three Lolium multiflorum accessions were used in the experiments: Traditional, Lucero and Picaflor. Seeds of Traditional accession were collected from old-field successional communities from Inland Pampa sub-region (34º6'S, 60²5'W) in 1998. Frequency of infection with Neotyphodium endophytes in this population was $85 \%$. Half of the collected seeds were treated with triadimenol fungicide $(150 \mathrm{~g}$ a.i. $/ \mathrm{kg})$ to generate the non-infected biotype (E-). Treated and untreated seeds were sown in soil free of L. multiflorum seeds. When E- seedlings had 2-3 leaves, they were sprayed with benomyl fungicide (500 $\mathrm{g}$ a.i. $/ \mathrm{kg}$ ). Seeds of both biotypes (Traditional E- and Traditional E+) were annually cultivated for 5 years in contiguous plots allowing cross pollination between them in order to reduce possible genetic differences.

Seeds of Lucero and Picaflor accessions were hand-collected from different grassland fields in 2003. Both accessions showed endophyte infection levels of more than $90 \%$. E- biotypes were generated as described before. Treated (Lucero E- and Picaflor E-) and untreated (Lucero E+ and Picaflor E+) seeds were sown in 2004 in contiguous plots on soil free of L. multiflorum seeds and cross pollination between them was allowed.

Seeds of the F6 generation of Traditional and F1 of Lucero and Picaflor accessions, produced during the natural growing season of 2004 were used. All the accessions were cultivated in adjacent plots in the experimental field at the Faculty of Agronomy

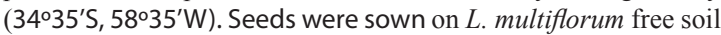
and cross pollination of plants was allowed. Produced seeds were hand-harvested and stored in glass jars at room temperature until the experiments. Seeds had 3 months of after-ripening when the experiments were carried out in 2005.

\section{Endophyte infection level}

The endophyte infection level of each accession was evaluated under light microscopy (Latch et al. 1987), using the Rose Bengal technique (Bacon \& White 1994). One hundred seeds per accession biotype were evaluated.

\section{Accelerated ageing experiments}

One E+ and E- seed lot (6 g) per L. multiflorum Traditional, Lucero, and Picaflor accessions was used. To adjust seed to high moisture content, seeds were exposed to a water saturated 
Table 2 Seed moisture content of biotypes of L. multiflorum accessions, Traditional, Lucero and Picaflor, during storage and after the humidification treatment (SD in brackets). Seed moisture content (\%) was measured on one sub-sample of $0.2 \mathrm{~g}(\approx 100$ seeds) of seed per biotype during storage and on three sub-samples of $0.2 \mathrm{~g}$ of seed per biotype.

\begin{tabular}{lccc}
\hline \multirow{2}{*}{ Accession } & \multirow{2}{*}{ Biotype } & \multicolumn{2}{c}{ Seed moisture content (\%) } \\
& & During storage & After the humidification \\
\hline Traditional & E+ & 12.00 & $14.23(1.17)$ \\
\multirow{2}{*}{ Lucero } & E- & 12.03 & $12.95(0.33)$ \\
& E+ & 10.09 & $14.13(0.96)$ \\
Picaflor & E- & 9.40 & $12.85(0.12)$ \\
& E+ & 11.47 & $15.66(0.06)$ \\
& E- & 11.48 & $14.54(1.19)$ \\
\hline
\end{tabular}

Table 3 Equation of linear regressions that describe seed viability in probit units $(v)$ in relation to incubation time $(D)$ under accelerated ageing condition of biotypes of $L$. multiflorum accessions: Traditional, Lucero and Picaflor. $D_{50}$ : time (days) to reach $50 \%$ of viability.

\begin{tabular}{lccccc}
\hline Accession & Biotype & Linear equation & $\mathrm{R}^{2}$ & $\sigma$ & $D_{50}$ \\
\hline Traditional & $\mathrm{E}+$ & $v=3.73-0.16 D$ & 0.94 & -6.00 & 22.42 \\
\multirow{2}{*}{ Lucero } & $\mathrm{E}-$ & $v=3.71-0.17 \mathrm{D}$ & 0.93 & -5.72 & 21.21 \\
& $\mathrm{E}+$ & $v=3.79-0.18 D$ & 0.91 & -5.67 & 21.46 \\
Picaflor & $\mathrm{E}-$ & $v=3.07-0.11 \mathrm{D}$ & 0.92 & -8.65 & 26.57 \\
& $\mathrm{E}+$ & $v=3.64-0.17 \mathrm{D}$ & 0.92 & -5.78 & 21.04 \\
& $\mathrm{E}-$ & $v=3.52-0.16 D$ & 0.92 & -6.34 & 22.33 \\
\hline
\end{tabular}

atmosphere for 6 hours. Seeds of each biotype were placed in a humidification closed plastic box $(21 \times 15 \times 5 \mathrm{~cm})$ above distilled water at $10^{\circ} \mathrm{C}$ with a plastic net $(1 \mathrm{~mm}$ mesh) placed $1 \mathrm{~cm}$ above a liquid water lamina of $1 \mathrm{~cm}$. The seeds were distributed on the plastic net. Seed moisture content was gravimetrically determined before (during storage) and after the humidification process, by weighing seeds (fresh weight), drying at $130^{\circ} \mathrm{C}$ for 1 hour, and reweighing (dry weight) (ISTA 1996). Seed moisture content was expressed in percentage on fresh weight basis as: $\mathrm{g}$ $\mathrm{H}_{2} \mathrm{O} / 100 \mathrm{~g}$ fresh weight (Table 2). Finally, each seed lot was held inside a hermetically sealed glass jar, and incubated in a growth chamber at $40 \pm 0.5^{\circ} \mathrm{C}$.

Seed viability dynamics in relation to storage time were determined on three sub-samples of 30 seeds of each biotype taken every 5 days from each glass jar and incubated under optimal temperatures for germination: $15 / 25^{\circ} \mathrm{C}$ alternating temperature (ISTA 1996). Seeds were sown in $9 \mathrm{~cm}$ diameter Petri dishes on filter paper moistened with $5 \mathrm{ml}$ distilled water. Germination (radicle protrusion) was recorded after 5 days and germinated seeds were removed from the dish, until no further germination was recorded. Non-germinated seed was considered to be nonviable. Germination speed or germination rate per day, a direct measure of the seed vigour, was estimated as the proportion of germinated seed during the first 5 days divided by five.

\section{Data analysis}

The dynamics of seed viability in relation to storage time were analysed by fitting a regression line for each biotype. According to Ellis \& Roberts (1980), seed viability loss can be described by the equation:

$$
v=K \mathrm{i}-D / \sigma
$$

where $v$ is viability proportion (probit units) after $D$ days under constant storage condition; $K \mathrm{i}$ is a constant specific to the seed lot and $\sigma$ is the standard deviation of the frequency distribution of number of seed deaths in time $(D)$. The effect of endophyte infection level on seed viability was tested by comparing slopes and $y$-intercepts of the regression lines between biotypes of the same accession.

The germination vigour was analysed by means of two way analysis of variance, considering endophyte infection status (E+ and E-) and time of incubation as sources of variation. Differences in vigour between biotypes at each extraction time were assessed by LSD test.

\section{Results and Discussion}

Endophyte infection level in E+ biotype of all accessions was near $90 \%$ while that of E- biotypes was significantly lower (Table 1). The endophyte infection level did not affect seed viability loss in Traditional and Picaflor accessions, as accounted for by the slope $(\mathrm{P}>0.05)$ and the $\mathrm{y}$-intercept $(K \mathrm{~K}, \mathrm{P}=0.203$ and $\mathrm{P}=0.07$ respectively) of the equation that describes seed viability in relation to incubation time under accelerated ageing conditions (Table 3, Fig. 1). In turn, the rate of viability loss was higher for $\mathrm{E}+$ seeds than $\mathrm{E}$ - ones for the Lucero accession $(\mathrm{P}=0.001)$. Double interaction between endophyte infection status and incubation time on seed germination vigour was only observed for Traditional accession $(\mathrm{P}=0.022)$, and not for Picaflor $(\mathrm{P}=0.757)$ and Lucero $(\mathrm{P}=0.110)$ accessions. Endophyte had a slightly positive effect for Picaflor $(\mathrm{P}=0.035)$ and not for Lucero $(\mathrm{P}=0.111)$ (Fig. 1).

These results suggest that the endophyte effect would depend on the population genetic background and the evaluated process. 
All Traditional, Lucero and Picaflor accessions were grown in a common garden, and shared pollen as plants were able to freely cross-pollinate. However it is expected that the maternallytransmitted endophytes would maintain their specific genetic background associated with each accession (Sullivan \& Faeth 2004). Thus, seed phenotype from each accession results from the interaction between the genotypes of the host plant and that of the endophyte. It is noteworthy that endophyte infection did not affect seed viability, but negatively affected seed germination vigour of Traditional accession. On the other hand, the removal of endophytes from seeds of Lucero accession had a greater negative impact on seed viability than on the germination vigour. Finally the overall effect of endophyte infection was low in the Picaflor accession, as it did not change seed viability, and marginally affected germination vigour only at the beginning of accelerated ageing.
The general negative effect of endophyte infection on seed longevity observed under the tested ageing conditions can be explained in part, considering that $\mathrm{E}+$ seeds were able to achieve higher moisture contents than E- (Table 2) and that there is a negative correlation between seed moisture content and seed longevity (Ellis \& Roberts 1980). The parameters of the viability equation were developed, in part, to detect seed quality differences between species and seed lots within a species (McDonald 1998). Despite $K$ i being used as a characteristic of each species (Ellis \& Roberts 1980), it is not uncommon to find variations among different seed lots of the same species (Walters 1998). In our experiments endophyte infection in the Lucero accession modified the parameters of the seed viability equation, increasing $K \mathrm{i}$ and diminishing $\sigma$ comparatively to non-infected seeds (i.e. narrowing the distribution of dead seeds in the population). Even if this result was the outcome of a confounded effect of endophyte

Figure 1 Seed viability (left panel) and germination vigour (right panel) of $E+(\boldsymbol{\Xi})$ and $E-(\Delta)$ biotypes of $L$. multiflorum in relation to incubation time under accelerated ageing condition for Traditional (upper set), Lucero (middle set) and Picaflor (lowest set) accessions. In the left panels straight lines indicate the fitted linear equation models for each biotype that describe seed viability as a function of time. On the right panels, the asterisks indicate significant differences between biotypes at each extraction time (LSD, $\mathrm{P}<0.05)$.

\section{Traditional}
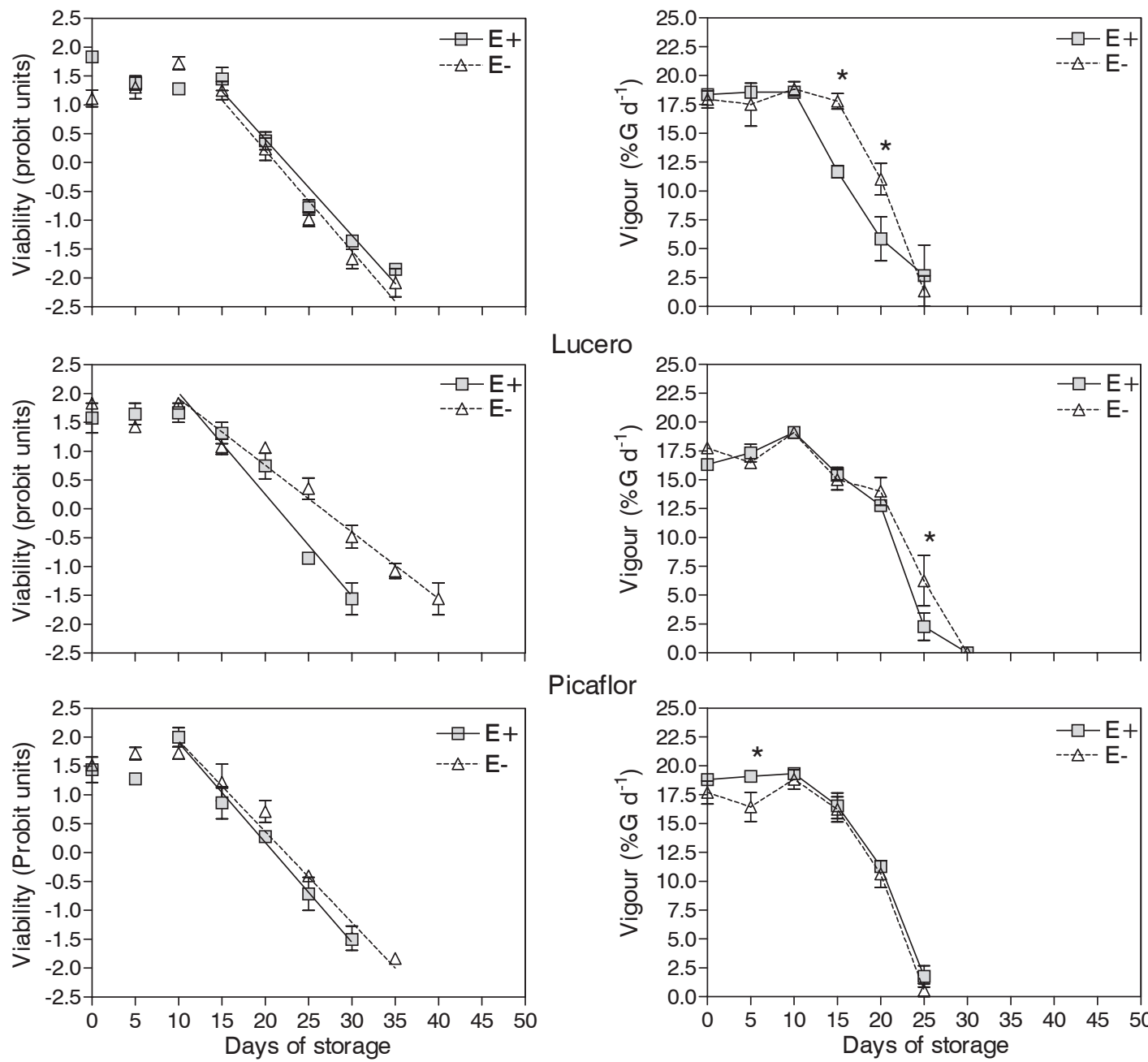

Picaflor

Lucero
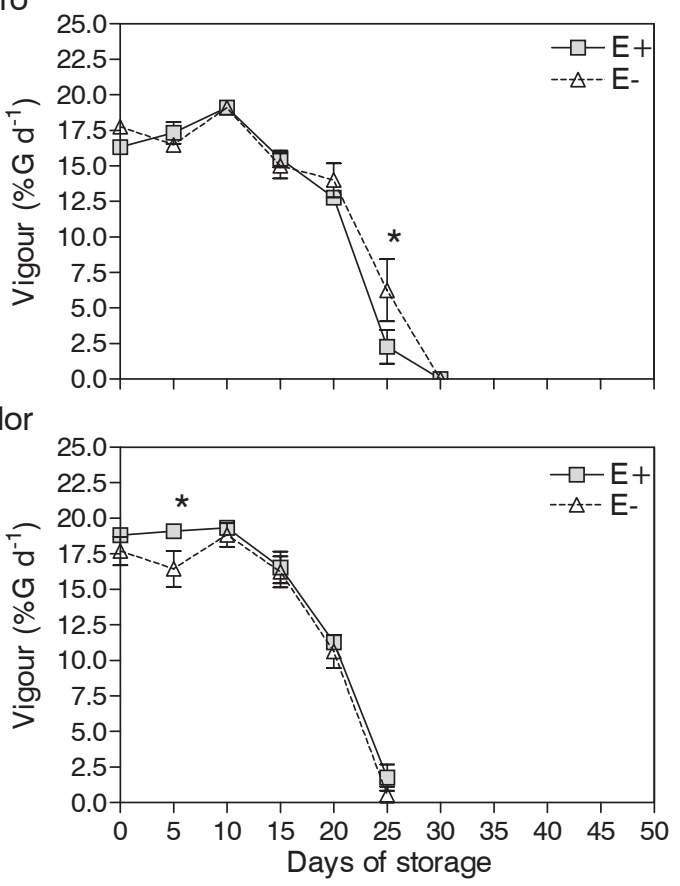
presence and the increase in moisture content, this variability in water content would be related to direct or indirect effects of the fungal infection on the seed morphological or physiological characteristics, which merits further investigations.

\section{REFERENCES}

Bacon, C.W.; White, J.F.Jr. 1994. Stains, media, and procedures for analyzing endophytes. pp. 47-56. In: Biotechnology of Endophytic Fungi of Grasses. Eds. Bacon, C.W.; White, J.F.Jr. CRC Press, Boca Raton.

De Battista, J.P. 2005. Neotyphodium research and application: current trends in South America. pp. 65-71. In: Neotyphodium in Cool-Season Grasses. Eds. Roberts, C.; West, C.P.; Spiers, D. Blackwell Publishing, US.

Ellis, R.H.; Roberts, E.H. 1980. Improved equations for the prediction of seed longevity. Annals of Botany 45: 13-30.

Gundel, P.E.; Maseda, P.H.; Vila-Aiub, M.M.; Ghersa, C.M.; Benech-Arnold, R.L. 2006a. Neotyphodium fungi effects on Lolium multiflorum seed germination in relation to water availability. Annals of Botany 97: 571-577.

Gundel, P.E.; Maseda, P.H.; Ghersa, C.M.; Benech-Arnold, R.L. 2006b. Neotyphodium endophyte effects on dormancy and germination rate of Lolium multiflorum seeds. Austral Ecology 31: 767-775.

Hume, D.E.; Barker, D.J. 2005. Growth and management of endophytic grasses in pastoral agriculture. pp. 201-226. In: Neotyphodium in Cool-Season Grasses. Eds. Roberts, C.; West, C.P.; Spiers, D. Blackwell publishing, US.

International Seed Testing Association. 1996. International rules for seed testing. Seed Science and Technology, 27, Supplement, Rules.

Latch, G.C.M.; Potter, L.R.; Tyler, B.F. 1987. Incidence of endophytes in seeds from collections of Lolium and Festuca species. Annals of Applied Biology 111: 59-64.

Marshall, A.H.; Naylor, R.E.L. 1985. Seed vigor and field establish- ment in Italian ryegrass. Seed Science \& Technology 13: 781-794.

McDonald, M.B. 1998. Seed quality assessment. Seed Science Research 8: 265-275.

Medvescigh, J.; Maidana, A.; De Battista, J.; Costa, M. 2004. Annual ryegrass endophyte viability evolution under storage conditions. pp. 514-516. In: Proceedings of the $5^{\text {th }}$ International Symposium on Neotyphodium/Grass Interactions, Fayetteville, Arkansas, USA.

Moon, C.D.; Scott, D.B.; Schardl, C.L.; Christensen, M.J. 2000. The evolutionary origins of Epichlöe endophytes from annual ryegrasses. Mycologia 92: 1103-1118.

Omacini, M.; Chaneton, E.J.; Ghersa, C.M.; Müller, C.B. 2001. Symbiotic fungal endophytes impact on insect host-parasite interaction webs. Nature 409: 78-81.

Rolston, M.P.; Hare, M.D.; Moore, K.K.; Christensen M.J. 1986. Viability of Lolium endophyte fungus in seed stored at different seed moisture contents and temperature. New Zealand Journal of Experimental Agriculture 14: 297-300.

Soriano, A.; León, R.J.C.; Sala, O.E.; Lavado, R.S.; Deregibus, V.A.; Cahuepé, M.A.; Scaglia, O.A.; Velázquez, C.A.; Lemcoff, J.H. 1992. Río de la Plata grasslands. pp. 367407. In: Ecosystems of the World 8A. Natural Grasslands. Introduction and Western hemisphere. Ed. Coupland, R.T. Elsevier, New York, US.

Sullivan, T.J.; Faeth, S.H. 2004. Gene flow in the endophyte Neotyphodium and implications for coevolution with Festuca arizonica. Molecular Ecology 13: 649-656.

Vila-Aiub, M.M.; Gundel, P.E.; Ghersa, C.M. 2005. Fungal endophyte infection changes growth attributes in Lolium multiflorum Lam. Austral Ecology 30: 49-57.

Walters, C. 1998. Understanding the mechanisms and kinetics of seed aging. Seed Science Research 8: 223-244.

Welty, R.E.; Azevedo, M.D.; Cooper, T.M. 1987. Influence of moisture content, temperature, and length of storage on seed germination and survival of endophytic fungi in seeds of tall fescue and perennial ryegrass. Phytopathology 77: 893-900. 